\title{
Het einde is nog niet in zicht...
}

\author{
Citation for published version (APA):
}

Nijhuis, J. (2018). Het einde is nog niet in zicht... Maastricht University. https://doi.org/10.26481/spe.20180621jn

Document status and date:

Published: 21/06/2018

DOI:

10.26481/spe.20180621jn

Document Version:

Publisher's PDF, also known as Version of record

\section{Please check the document version of this publication:}

- A submitted manuscript is the version of the article upon submission and before peer-review. There can be important differences between the submitted version and the official published version of record.

People interested in the research are advised to contact the author for the final version of the publication, or visit the DOI to the publisher's website.

- The final author version and the galley proof are versions of the publication after peer review.

- The final published version features the final layout of the paper including the volume, issue and page numbers.

Link to publication

\footnotetext{
General rights rights.

- You may freely distribute the URL identifying the publication in the public portal. please follow below link for the End User Agreement:

www.umlib.nl/taverne-license

Take down policy

If you believe that this document breaches copyright please contact us at:

repository@maastrichtuniversity.nl

providing details and we will investigate your claim.
}

Copyright and moral rights for the publications made accessible in the public portal are retained by the authors and/or other copyright owners and it is a condition of accessing publications that users recognise and abide by the legal requirements associated with these

- Users may download and print one copy of any publication from the public portal for the purpose of private study or research.

- You may not further distribute the material or use it for any profit-making activity or commercial gain

If the publication is distributed under the terms of Article $25 \mathrm{fa}$ of the Dutch Copyright Act, indicated by the "Taverne" license above, 
Prof. dr. Jan G. Nijhuis

Faculty of Health, Medicine and Life Sciences

\section{Het einde is nog niet in zicht...}




\section{Afscheidsrede van prof. dr. Jan G. Nijhuis, hoogleraar verloskunde aan de Universiteit van Maastricht en het MUMC (jg.nijhuis@mumc.nl). Gehouden op donderdag 21 juni 16:30 uur.}

Geachte leden van het College van Bestuur en Raad van Bestuur van ons MUMC+, beste collegae, familie en vrienden.

\section{Het einde is nog niet in zicht...}

Toen ik een tijd geleden deze titel met een goede vriend besprak, zei hij.... 'Nou Jan het kon wel eens sneller gaan dan je denkt'. Zo had ik het natuurlijk niet bedoeld, we zullen zien.

Maar laat ik beginnen bij Haraucourt (1856 - 1941) en zijn 'Rondel de l'adieu' uit 1891. In de eerste zin van dat gedicht staat wat ik heel vaak bij een afscheid van een medewerker heb gezegd, namelijk 'partir c'est mourir un peu', vertrekken is een beetje doodgaan. Dat is zeker ook vandaag waar voor mij, zeker als je vertrekt uit 'bijna de leukste baan van Nederland'.

In deze afscheidsrede ga ik met u verschillende onderwerpen bespreken. Het doel is dat ik u zaken met u spiegel, waarbij het van belang is dat $u$ dan anders tegen verschillende zaken aan gaat kijken. Ik laat u zien dat de een in deze 'illusie' een romantisch plaatje ziet van een echtpaar dat over een meer uitkijkt, terwijl een ander juist de baby ziet de ook te zien is.

Ik ga het met $\mathrm{u}$ hebben over foetaal gedrag en vraag me af 'its all in the genes'? En als alles in de genen zit, kunnen we er dan niets meer aan doen? Vervolgens spreken we over de babysterfte rondom de geboorte ('perinatale sterfte') en beantwoord ik de vraag of we vooruit gaan. Daarna doemt dan de vraag op of de zwangere wel echt 'centraal' staat en hoe de zorg beter zou kunnen in deze moderne tijd. En tenslotte leg ik uit waarom ik bijna de leukste baan van Nederland heb. En als je anders naar dingen gaat kijken, weet je ook dat je moet veranderen, en veranderen is meestal een moeizaam proces. Al rond 1800 was het Alexander Humboldt (1769-1859) die liet zien dat bijna iedereen eerst zegt dat een idee of verandering onzinnig is, daarna dat er 'misschien wel iets in zit' en uiteindelijk wordt het prima gevonden. In de moderne tijd ervaren we dat ook en vooral veranderingen van organisatie cultuur zijn moeilijk, want 'culture eats strategy for lunch'.

In de afgelopen jaren is duidelijk geworden dat een foetus niet een 'inert wezen' is tot de geboorte, maar 'gewoon een mens'. De foetus kan al vroeg bewegen, adem- 
bewegingen maken, gapen, en uitstrekken en rekken zoals hij dat steeds op dezelfde wijze zal doen, de rest van zijn leven. Alleen het patroon verandert, omdat het brein rijpt. Dat is wat we in de afgelopen decennia gedaan hebben, we hebben meer inzicht gekregen in de foetale black box.

Dat zie je ook als je naar een CTG kijkt, een registratie van de foetale hartactie, bij 32 en 41 weken. $U$ ziet versnellingen bij bewegingen, acceleraties. Maar bij een kind van 32 weken zijn die nog klein, bij 41 weken opvallend groot. Het kind wordt sterker en wordt ook wakkerder, we hebben dat een 'jogging fetus' genoemd. Je ziet dat ook bij lichaamsbewegingen die steeds langer afwezig kunnen zijn. Bij 10 weken kan de foetus niet langer dan een minuut of 5 stilliggen bij 40 weken kan de foetus dat wel zo'n 40 minuten. Datzelfde patroon zie je ook bij adembewegingen: bij 10 weken kunnen deze maximaal een minuut of 20 afwezig zijn, bij 40 weken kan dat oplopen tot wel 130 minuten. Dus naarmate het foetale brein meer rijpt, kan de foetus beter stilliggen, stilliggen is een kunst.

Als we dan steeds beter snappen dat de foetus gewoon een zich ontwikkelend mens is, kunnen we ook begrijpen dat een foetus al kan leren en een geheugen heeft. Wij hebben laten zien dat als je een specifieke prikkel geeft, de foetus daar in het begin op reageert met onverwachte bewegingen, hij schrikt of is angstig, en na verloop van tijd went de foetus, net als wij. Als wij bij een treinstation gaan wonen, horen we in het begin elke trein, maar na enige tijd is het alsof we dat geluid niet meer horen. We hebben laten zien dat foetussen die 'getraind' of 'gehabitueerd' zijn, bij 38 weken nauwelijks meer reageren op de oorspronkelijke prikkel, terwijl een controlegroep bij 38 weken heel heftig blijt reageren. De foetus heeft dus een geheugen.

En als die foetus dus gewoon een mens is, kan die ook wakker worden, Eerder hebben we laten zien hoe je met behulp van echoscopie en CTG's slaap en wakker bij de foetus kunt definiëren ('gedragstoestanden' volgens de definities van Nijhuis). In onderzoek bij foetussen van 38 weken en 41 weken hebben we gezien dat de foetus minder gaat slapen, en de foetus van 41 weken is veel meer wakker dan bij 38 weken. Datzelfde onderzoek is gedaan bij baby's die bij 38 weken geboren zijn en nog eens drie weken later, dus ook 41 weken, De uitkomsten zijn eigenlijk identiek. Dus: "de foetus wordt wakker, met of zonder geboorte'. Het is goed te beseffen dat 'geboorte' dus ontwikkeling neurologisch niet veel betekent. Bij de geboorte moet de foetus eerst constant gaan ademen, denken aan temperatuurregulatie, voeding, etc., pas daarna komt de verdere neurologische ontwikkeling weer een stap verder. 
Maar wat nog veel opvallender is: zelfs persoonlijkheid en gedrag liggen voor de geboorte al vast. Prof. Nancy Segal uit Californië doet psychologisch onderzoek identieke, dus eeneiige tweelingen, die gescheiden zijn opgegroeid, door adoptie of verwisseling. Daarvan zijn er niet zo veel. Een voorbeeld is een Koreaanse tweeling waarvan de een in Frankrijk en de andere in de VS opgegroeid is. Heel interessant is het boek 'Accidental brothers', dat vorige maand uitkwam, over twee eeneiige tweelingen die verwisseld zijn. Wilber en William Velasco zijn opgegroeid als tweeeiige tweeling in een arme streek in bij Santander het noorden van Colombia, Carlos en Jorge Castro in het rijkere Bogota. Maar eigenlijk zijn Willam en Jorge een tweeling, en Carlos en Wilber ook. Dan is er, als de jongens 24 jaar oud zijn, in 2014 de kennis die op bezoek is in het andere deel van Colombia en denkt dat zij William ziet, maar het is Jorge. Via facebook etc. gaat de bal dan rollen en wordt duidelijk dat bij de ziekenhuis opname tijdens en na de bevalling Carlos en William verwisseld zijn. Carlos heeft zich ook altijd een 'outlyer' gevoeld in het gezin in Bogota, William heeft zich daarentegen nooit echt thuis gevoeld in het arme Santander, hij wilde altijd meer. Er volgt een ontmoeting en dan wordt iedereen duidelijk hoezeer ook de karakters van de eigenlijke tweelingen identiek zijn. Psychologisch onderzoek van Segal kijkt naar heel veel gedragsfacetten en competenties als ambitie, intelligentie, empathie, etc. bij deze jongens. En het is duidelijk dat de eeneiige tweelingen feitelijk identiek zijn, ondanks het feit dat de een arm en de ander rijker is opgevoed. Ik vind dit fascinerend. U kunt het boek gewoon kopen, prachtig leesbaar, en ik heb geen belangenverstrengeling te melden.

Maar als het allemaal al vastligt, kunnen we er dan nog wat aan veranderen? En wat betekent dit voor de nature / nurture discussie. Dan blijkt het einde nog niet in zicht... Zeker zijn er nog wel een paar punten. Bijvoorbeeld voeding, stress, medicatie en andere zaken kunnen een kind wel beschadigen, ook al ligt het feitelijke karakter vast. Kinderen geboren tijdens de hongerwinter in de $2^{\mathrm{e}}$ wereldoorlog krijgen vaker hoge bloeddruk en suikerziekte. Dat zijn epigenetische veranderingen. Het was prof. David Barker die dat de 'developmental origins of health and disease', DOHaD, noemde. En dat is weer een heel nieuw wetenschappelijk onderzoeks veld geworden.

En natuurlijk kunnen we het nog fout doen bij de zorg tijdens zwangerschap en geboorte, en dat brengt me bij het Euro - Peristat onderzoek, naar onder andere de 
perinatale sterfte, sterfte rondom zwangerschap en geboorte (www.europeristat.com). Toen het eerste onderzoek uitkwam, bleek dat Nederland het helemaal niet goed deed. Vergelijking van data uit 29 landen van de Europese Unie, liet zien dat Nederland bij de top 4. Alleen de 'top' is de hoogste sterfte, dus geen goed nieuws. Dat was een enorme schok, en de kranten uit die tijd laten zien hoe men reageerde. Niemand wilde het eigenlijk geloven, staatssecretaris Ross zei dat het onderzoek niet deugde, etc. Als dit in deze tijd zou gebeuren, zou iedereen zeggen dat het 'fake news' is, maar dat begrip kenden we toen nog niet. $U$ ziet, weer het Humboldt effect. ledereen begon te ontkennen, ook wel typisch Nederlands. Immers, we denken dat we het beste voetbalteam van de wereld hebben, alleen..., we winnen nooit. We doen zelfs niet eens meer mee aan de wereldkampioenschappen.

Gelukkig gingen we na enige tijd toch serieus zaken onderzoeken en de kranten worden dan ook voorzichtiger, de erkenning komt dat we echt een probleem hebben. En dat is maar goed ook, want sterfte is slechts het topje van de ijsberg, het gaat niet alleen om sterfte, maar ook over handicaps zoals spasticiteit en longschade die kunnen ontstaan bij onvoldoende zorg.

Dus 'misschien zit er wel wat in', zette ons aan het denken en aan het werk. Zowel de zorgverleners (zoals verloskundigen, gynaecologen en kinderartsen) als de landelijke organisaties (zoals NVK, KNOV, NVOG) gingen aan het werk. We gingen beter letten op groeivertraging, vroeggeboorte, wat te doen met 'minder leven' voelen, we gingen meer echo's doen en bij twijfel eerder inleiden.

Daarnaast kwam ook VWS in actie, samen met die beroepsgroepen. We ontwikkelden Perinatale Audit, er kwamen verloskundige samenwerkingsverbanden, het College Perinatale Zorg werd op gericht en de landelijke perinatale registratie en audit werden efficiënt samengebracht in Perined.

Dit zijn natuurlijk maar een paar punten uit de vele acties die ondernomen zijn toen we eenmaal accepteerden dat de cijfers wel waar waren. Zo wisten we ook dat de sterfte na 41 weken zwangerschapsduur wat stijgt. We zijn daarom vaker al bij 40 tot 41 weken gaan inleiden. Een dramatische afname van geboorten na 41 weken was het gevolg en een geboorte bij 42 weken komt eigenlijk niet meer voor, een afname van $75 \%$ in 10 jaar, en dus ook een afname van sterfte. 
En al deze inspanningen hadden effect. We vergelijken Nederland en Finland, een land dat het echt heel goed doet. In 2005 zitten we echt veel hoger, maar we groeien sterk naar elkaar toe omdat de sterfte in Nederland sterk gedaald is in de afgelopen 10 jaar. Maar wat ook interessant is dat de sterfte verschillen met Finland vooral voor 25 weken en na 32 tot 34 weken opvallend waren. Voor 25 weken is te begrijpen, want dan zijn we in Nederland nog niet echt actief, en Finland al wel. Met veel dank aan Peter Achterberg van het RIVM die deze grafieken mede vorm gaf.

Dan komt de fase van de geboortes tussen 25 en 32 weken, die zorg speelt zich af in de 10 ziekenhuizen die ook een Neonatale intensive Care unit, een NICU hebben (de acht academische ziekenhuizen en Veldhoven en Zwolle). In die periode deden we het even goed als Finland. Maar vanaf 32-34 weken lopen we weer uit de pas, en veel aandacht is daarom ook gegaan naar de perinatale sterfte in de laatste weken van de zwangerschap. Dan is het aantal ziekenhuizen veel groter, dan komt de eerste lijn er ook bij, en het lijkt alsof we dan wat meer op de natuur vertrouwen. En natuurlijk ook, meer zorgverleners met het risico van meer communicatie stoornissen, want iedereen kijkt op zijn eigen wijze. Maar ook dat verschil is in tien jaar veel minder geworden, het is duidelijk dat al onze inspanningen zinvol bleken. En we kunnen onze cijfers ook vergelijken met Vlaanderen. Dee sterfte na 37 weken zwangerschapsduur is in de laatste jaren sterk afgenomen en we benaderen Vlaanderen inmiddels, een deel van België waar ze het echt goed doen. Het is meer aandacht en ook betere communicatie, Nederland heeft immers ook nog huisartsen, verloskundigen, kinderartsen en gynaecologen die allemaal moeten samenwerken.

En zijn we nu dan klaar, nee, het einde is nog steeds niet in zicht...

We hebben nog een paar zaken die niet onbesproken mogen blijven op weg naar de toekomst. Dan gaat het vooral over de vraag of we de zwangere wel echt centraal stellen, zoals we zo graag beweren. Daarnaast de vraag hoe het zit met de ziekenhuizen en wat zij 24/7 moeten kunnen leveren. En tenslotte de druk op de zorgverleners, waar we toch ook niet omheen kunnen.

Allereerst de organisatie van verloskundige zorg. Als je zwanger bent, je bent goed gezond, er is dus geen medische indicatie, dan is de norm dat je naar de verloskundige gaat en thuis bevalt. Je kunt ook kiezen voor poliklinisch bevallen zonder indicatie, maar dan moet je wel een eigen bijdragen van rond $€ 400$ betalen, 
tenzij je een wat duurdere verzekering hebt. Dat noemen we $1^{\mathrm{e}}$ lijns zorg. $2^{\mathrm{e}}$ lijns zorg wordt geleverd door de gynaecoloog en daar mag je alleen naar toe als je een medische indicatie hebt.

Maar hoe werkt dat nu echt in de dagelijkse praktijk?

Het percentage thuisbevallingen is in de afgelopen 15 jaren van bijna $40 \%$ naar ruim $12 \%$ gedaald. Voor het eerste kind is dit cijfer nog veel lager, namelijk $7.5 \%$ en voor het tweede en derde kind iets hoger $16.8 \%$.

In Nederland starten bijna 90\% van alle zwangeren de zorg in de eerste lijn, waarschijnlijk met de verwachting ook onder begeleiding van de verloskundige te bevallen. Laten we kijken naar de zwangerschap van het eerste kind. Tijdens de zwangerschap kun je verwezen worden naar de $2^{\mathrm{e}} \mathrm{lijn}$, bijvoorbeeld omdat het kind te groot of te klein is, de zwangere hoge bloeddruk ontwikkelt, etc. In 2016 betekent dat er van de ruim 65000 zwangeren die hun eerste kind verwachtten, er ruim 25000 verwezen werden, $40 \%$. De overgebleven 39.500 zwangeren startten de bevalling van hun eerste kind in de eerste lijn, thuis of poliklinisch. Dus die zijn goed gezond, goede zwangerschap gehad en gaan nu bevallen. ledereen kan denken wat een reëel verwijzingspercentage zou zijn, maar feit is dat dat percentage $61 \%$ is, bijna 25000 zwangeren werden tijdens de bevalling van hun eerste kind verwezen. Dus als je je eerste kind krijgt, is de kans dat je in de eerste lijn bevalt slechts $21 \%, 7.5$ thuis en $13.5 \%$ poliklinisch.

Als je je $2^{\mathrm{e}}$ of $3^{\mathrm{e}}$ kind krijgt, zien de cijfers er beter uit, maar het is aan $\mathrm{u}$ of $\mathrm{u} 37 \%$ geslaagde bevallingen in de eerste lijn veel of weinig vindt.

De grote vraag is ook of we dit eerlijk vertellen en of zwangeren keuzes hebben. Zelfs in de politiek is dit niet altijd duidelijk, te meer daar 'tellers en noemers' verwisseld worden.

$\mathrm{Er}$ is een interessante brief van minister in Schippers in 2016 aan de $2^{\mathrm{e}}$ kamer over de verloskundecijfers in 2014. In 2014 begon 86\% van alle zwangeren (dus moeders met het eerste kind, en $2^{\mathrm{e}}$ en $3^{\mathrm{e}}$ kind) de controles in de $1^{\mathrm{e}}$ lijn. Dat klopt. Daarnaast schreef zij dat 35\% wordt verwezen tijdens de zwangerschap en $22 \%$ tijdens de bevalling. Dan gaat het over de verwijzingen als percentage van alle zwangeren. Maar dat is natuurlijk niet interessant. Wat je als zwangere wilt weten, is wat jouw kans op verwijzing is als je in de eerste lijn aan je bevalling begint. Dus tellers en noemers. Als je die relevante cijfers wilt melden is dat $41 \%$ en $44 \% \ldots$, dat klinkt toch wel even anders. 
En als de politiek dat niet helder heeft, komt de vraag: "weten de zwangeren dat allemaal". Wel...., we hebben een interessante folder 'zwanger' die 35 pagina's dik is en waar veel over de zwangerschap en kraambed wordt gemeld. De verschillende beroepsgroepen, onder andere huisartsen, kinderartsen, verloskundigen gynaecologen, apothekers en het RIVM trekken hier gezamenlijk in op. In de folder die in 2015 nog gebruikt werd en ook op het internet stond, geven ze gelukkig aan dat ze in deze folder 'betrouwbare informatie' geven, dat is toch ook heel fijn. Als je de folder leest, word je zeker wijzer. Dan kom je ook bij hoofdstuk 6 'voorbereiden op de bevalling'.... Dan verwacht je natuurlijk dat hoofdstuk 7 over 'de bevalling' gaat, dus over percentages verwijzingen, kunstverlossingen, de kans op een keizersnede, etc. Echter, hoofdstuk 7 is 'na de bevalling'.......

Dus waar is het hoofdstuk 'de bevalling' Toen ik daar openlijk wat over gezegd heb, is de folder gelukkig snel aangepast.

In 2017 kwam de nieuwe folder uit en inderdaad is nu een hoofdstuk 'de bevalling' toegevoegd. Maar staat het er nu goed en duidelijk in, de verwijskansen, de kans op een keizersnede etc., nog steeds niet echt in detail. Maar dat is misschien ook niet erg, want men heeft de opmerking dat het gaat om 'betrouwbare informatie', nu ook weggelaten.

In mijn perceptie is dit alles het gevolg van ons conservatisme, vaak hoor je 'we zijn gericht op de natuurlijke bevalling'. Maar we zouden gericht moeten zijn op 'een goed verloop van de bevalling, met een goede beleving". En ook de betrokkenheid van de zwangere zou zwaar moeten wegen.

In 2016 kregen $17.9 \%$ van de vrouwen die hun $1^{\mathrm{e}}$ kind kregen een keizersnede, bijna 1 op 5, en 14.9\% , 1 op 6 à 7, een vacuümextractie. Als je zwangeren niet goed en eerlijk informeert over deze hoge kansen blijft alleen teleurstelling over en vaak het gevoel dat men 'gefaald' heeft.

En met $7.5 \%$ kans op een succesvolle thuisbevalling kan dit toch niet de norm zijn, en als je $80 \%$ kans hebt in de $2^{\mathrm{e}}$ lijn te bevallen, waarom mag je dan niet zelf kiezen voor de $2^{\mathrm{e}}$ lijn.

Mijn advies is afschaffen van de eigen bijdrage en geef zwangeren een echte vrije keus.

Een prachtig voorbeeld is het Medisch Contact van 14 juni (afgelopen week). Een artikel over afgelopen weekend) staat een artikel dat gaat over welke organisatie het beste werkt en dat 'Invoering van integrale geboortezorg voorbarig is. En in het 
artikel geen woord over wat de zwangere wil, alleen over wat gynaecologen en verloskundigen zouden willen...

En dan 'wat gaan ziekenhuizen doen' en wat moet 24/7 beschikbaar zijn. Er zijn genoeg ziekenhuizen in Nederland, 10 miljoen mensen hebben 3 ziekenhuizen binnen 15 minuten. Natuurlijk zijn er gebieden waar weinig ziekenhuizen zijn, maar de vraag is hoe erg dat is. Je kunt niet alle vormen van zorg die je eenvoudig kunt concentreren op heel veel locaties realiseren. Want geboortezorg mag dan eenvoudig lijken, en de risico's op ernstige complicaties zijn niet zo heel groot, maar als het wel gebeurt, zijn de gevolgen groot. De vraag is dus of er dag en nacht een gynaecoloog 'in huis' is. Inn 2 op 3 ziekenhuizen is 's nachts een ruggenprik niet of met veel moeite mogelijk. Als er geen kinderarts 'in huis' is als een kind bij een bevalling ineens toch slap of in een niet verwachte slechte conditie geboren wordt, wat dan. Is er een OK-team in huis als je een spoedkeizersnede krijgt. En ... is er bij een ernstige bloeding een interventieteam aanwezig dat kan helpen, opdat je niet je baarmoeder verliest.

En is dat te vinden op elke website van elk ziekenhuis en moeten we daar de zwangeren niet over informeren?

En dan is er 'de druk op de zorgverlener'. Door alle veranderingen als protocollen, AVG, grote administratielast , toenemende regelgeving, onvoldoende teamwork, 'onveilige werkomgeving' en gebrek aan autonomie komt de zorgverlener onder druk te staan. Ook wordt het beschikbaar zijn voor diensten (ook al zijn die misschien niet druk) wordt als een ernstige last ervaren.

En hier ziet u de moderne problematiek, de druk wordt steeds hoger, een partner die ook een belangrijke baan heeft, een kind, afstanden, carrière, ambitie, kortom druk, druk, druk. De balans is zoek en burn-outs staan voor de deur.

Dit wordt ook door de media' wel gesignaleerd, maar de oplossing is nog niet echt in zicht. Dokters en verpleegkundigen worden schaarser en zijn niet meer altijd inzetbaar.

Je zag dat vorige maand in Stadskanaal waar de kinderartsen in kleine groepen niet meer 24/7 beschikbaar kunnen zijn, en als de kinderarts verdwijnt, verdwijnt ook de verloskunde. Maar gelukkig is er in Nederland altijd wel een ander ziekenhuis in de buurt. 
Dus er zijn genoeg ziekenhuizen, de druk is groot en tenslotte... kennis gaat snel". Zoals Erik-Jan Vlieger in zijn boek (het nieuwe brein van de dokter) laat zien verschijnt er momenteel één artikel in PubMed per 23 seconden. De halfwaardetijd van kennis gaat zo snel, dat het voor een gemiddelde dokter niet meer te volgen of bij te houden is.

Uit onderzoek is ook bekend dat de dokter nog steeds maar heel langzaam verandert, hij doet iets 'omdat hij het zo geleerd heeft......'.

Dus misschien moeten we vaststellen dat werken in kleine groepen zonder AIOS (arts-assistenten in opleiding tot specialist) niet meer zou moeten kunnen. En de snelheid van kennis vraagt om een andere manier van werken.

We hebben nu ziekenhuizen zonder AIOS, ziekenhuizen met AIOS, en academische ziekenhuizen. Deze werken allemaal zelfstandig, ze moeten zelfs concurreren, ze hebben niet identieke protocollen, er is een verminderd leervermogen, kortom niet efficiënt.

We moeten mijns inziens naar fusie en netwerkziekenhuizen, waarbij specialisten ook bijvoorbeeld 2 maanden per jaar in een ander ziekenhuis gaan werken, 'job rotation'. Er ontstaat dan een regionetwerk met AIOS en roulerende specialisten die net met elkaar concurreren en ze hebben dezelfde protocollen. Ook is er dan geen concurrentie meer tussen ziekenhuizen, het concurrentiebeding schaffen we af, ook de ziekenhuizen krijgen afdeling overschrijdende identieke protocollen, er ontstaat een verbeterd leervermogen en het geheel wordt efficiënter.

Het is ook bekend dat 'job rotation' goed werkt tegen burn-out gevoel, en dat dat voor de mens zelf en de organisatie verrijkend is.

Dan zijn we weer bij Humboldt..... u zult misschien denken, dat die ideeën van Nijhuis onzinnig zijn, maar misschien denkt u over een paar jaar dat het zo gek nog niet was, en is dit over enkele jaren wel gewoon realiteit.

Tja, dames en heren en waarom bijna de leukste baan van Nederland.

Laat ik allereerst zeggen hoe ik genoten heb van alle clubjes waar ik bij betrokken was, zowel professioneel als privé. Natuurlijk het ziekenhuis en faculteit met betrokkenheid van college en RvB, maar ook alle groepen daarbinnen, mijn RVE team, het stafconvent, de vele commissies, etcetera.

Dan meer nationaal, mijn NVOG, een beroepsgroep waar ik voorzitter van mocht zijn en waar ik ook weer leiding heb gegeven aan veel subgroepen. Voorbeelden zijn het 
oprichten van de werkgroep Otterlo en de voortgangstoets, het naar Nederland halen van de MOET, de cursus foetale bewaking. En natuurlijk vooral de mensen die dan steeds weer eigenlijk vrienden worden.

Natuurlijk ook Perined, niet te vergeten de Gezondheidsraad, en internationaal de Peristat groep en natuurlijk de Fetal and Neonatal Physiological Society, die de $45^{\mathrm{e}}$ bijeenkomst houdt van aanstaande zondag tot woensdag in Rolduc.

En dat alles natuurlijk door de jaren heen met veel steun van de hele staf obstetrie \& gynaecologie, met wie het werken bijna altijd een feest was, en natuurlijk mijn beide rechterhanden, mijn secretaresse Manon Gordijn en de manager bedrijfsvoering van onze afdeling, Gaby Palmen.

En dan alle privé clubjes, van koken tot dining, van golf tot sporten, van skiën tot oude vrienden, en jonge vrienden en natuurlijk het GGG het groot Gronsvelds Genootschap.

En natuurlijk mijn promovendi, ik ben trots op jullie en kijk met ontzettend veel genoegen terug op al die promotietrajecten. Wat was het soms eenvoudig en wat zat het soms tegen, maar het is altijd goed gekomen.

En dan onze staf en aios, hier bij de teambuilding... Door de jaren heen hebben we het niet altijd makkelijk gehad maar er staat nu een staf obstetrie \& gynaecologie, met wie het werken bijna altijd een feest is.

En de AIOS, wat een genoegen om elke keer weer het enthousiasme van de nieuwe generatie te zien, de AIOS houden je wakker en bij de weg. Zonder AIOS kun je in de moderne wereld het vak niet bijhouden en het is ook zo dat kennisoverdracht echt van beide kanten komt.

En dan is het natuurlijk bijna de mooiste baan van Nederland, omdat ik iedereen gun dat hij of zij de allerleukste baan van Nederland heeft.

En dan kom ik bij mijn familie, 7 kinderen, waarvan er drie hoogleraar werden, Frans, Ton en ik. Heel verdrietig dat Frans alweer bijna 3 jaar geleden overleden is, maar Ton zit in het cortège. Ik ben blij dat mijn andere drie broers en mijn zus ook aanwezig zijn.

Erkentelijk ben ik mijn ex-partner Marjan voor de jaren die we gehad hebben, de jaren waarin onze kinderen geboren zijn en volwassen zijn geworden.

Blij en gelukkig ben ik met Monique en ik hoop dat voor onze relatie geldt dat het einde nog lang niet in zicht is. 
En dan natuurlijk mijn kinderen, Tim, Annelijn, Olivier en de partners Jolien en Martijn. Wat ben ik ontzettend trots op jullie en op wat jullie allemaal presteren. En natuurlijk ben ik ook benieuwd naar wat er allemaal nog gaat gebeuren. In die zin hoop ik dat mijn einde nog niet in zicht is.

En natuurlijk, zoals dat gaat als je ouder wordt, eindig je met je kleinkind, Diederik, de zoon van Tim en Jolien. Wat is dat weer een andere dimensie, en ook bij hem zie dat het gedrag genetisch bepaald is. Prachtig om dit weer mee te mogen maken.

Dus dames en heren, ik weet dat het einde in de verloskunde nog niet in zicht is, en ik hoop dat dat voor $u$ allen en mezelf ook privé het einde nog niet in zicht is.

Ik dank u voor uw aandacht.

Ik heb gezegd. 